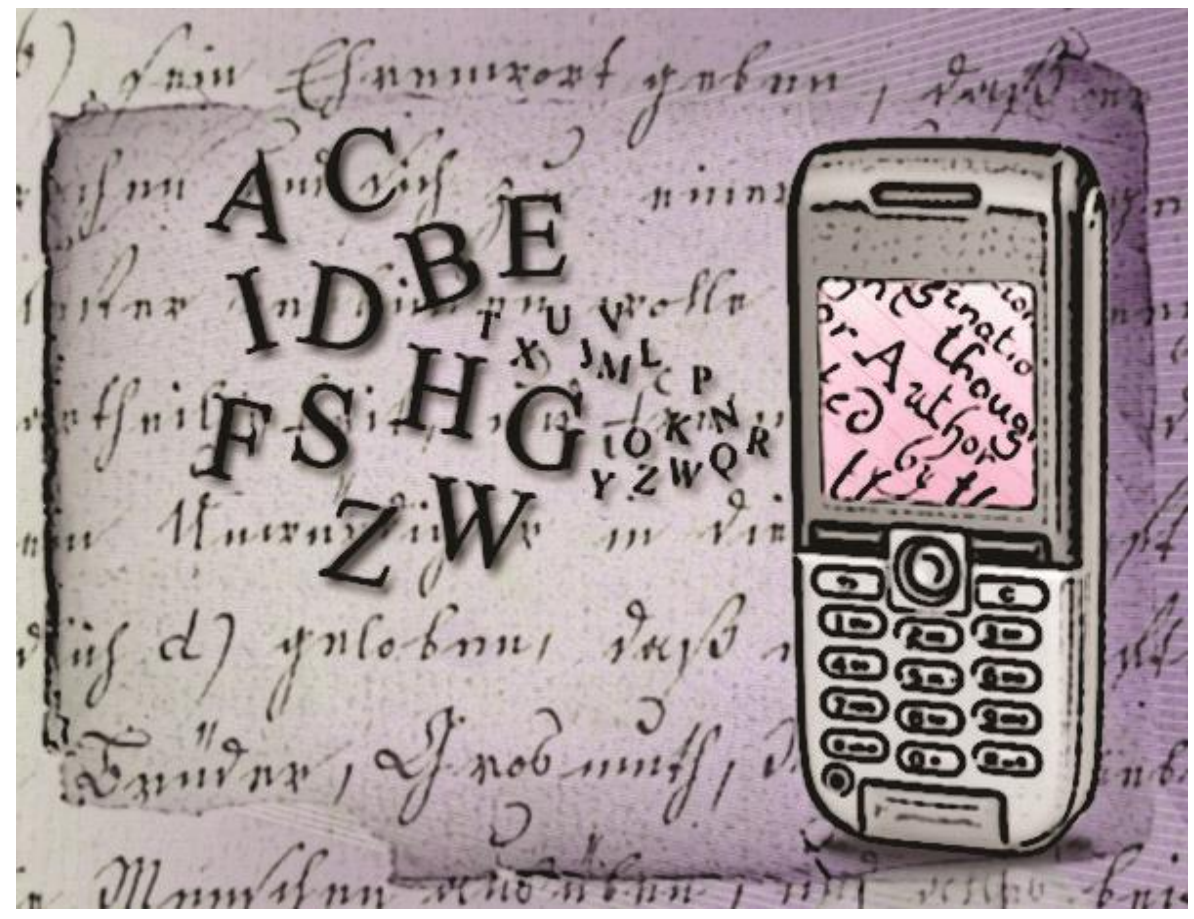

Felipe Mesquita

\title{
POESIA NO CELULAR
}

\section{Fernanda Ricardo Campos}

Formada em Letras, licenciatura plena em língua portuguesa, pela Pontifícia Universidade Católica de Minas Gerais (PUCMG). Especialista em Leitura e Produção de Textos pela Universidade Federal de Minas Gerais (UFMG) e professora do Departamento de Linguagem e Tecnologia do Centro Federal de Educação Tecnológica de Minas Gerais (CEFET-MG).

"Tive um sonho desbotado, de uma vida que nao fazia sentido.o caos significava que eu podia dete-lo,o sonho.Entao percebi uma beleza calma de prender os olhos."

O texto acima faz algum sentido pra você? Sem acentuação e espaço entre os caracteres o que ele parece? Bom, acertou quem respondeu um poema, mas mesmo assim você ainda estranha a falta de espaço e acentos? Então pense num poema escrito a partir de um aparelho celular. Está começando a entender?

No início do mês de novembro participei do II Prêmio Literatura no Celular realizado pela curadoria de literatura da $5^{a}$ edição da FLIPORTO (Festival Internacional de Literatura de Porto de Galinhas). Foi um concurso completamente 
interativo, eu fiz tudo pelo celular, incluindo a inscrição e o envio do poema. Podíamos convidar as pessoas a votar, elas conferiam o poema pelo site e votavam com o código do poema (cada poema recebia um ao se cadastrar)pelo próprio celular, desde que fosse uma conta da operadora que patrocinou - concurso. Tudo muito simples, fácil de ler, votar e participar, tanto para os escritores quanto para os amigos que votavam nos poemas, muito gostoso de fazer. É muito bacana ver que o mundo atual consolidou a ideia da mídia virtual. A transmutação dos suportes da poesia e da arte como um todo é uma realidade em movimento, pois foram mais de 250 poemas inscritos, vários acessos na página do concurso e muitos votos computados. Eu recebi alguns votos e não ganhei o concurso, mas pude perceber que a poesia precede 0 suporte e fica cada vez mais deliciosa... 